ISSN 2078-6441. Вісник Львівського університету. Серія географічна. 2013. Випуск 44. С. 286-294. Visnyk of the Lviv University. Series Geography. 2013. Issue 44. P. 286-294.

631.452:332.6

\author{
рин ліско \\ ціон льний н уковий центр \\ “нститут грунтозн вств m грохімї імені . . околовського”, \\ вул. йковськ, 4, 61024, м. рків, кр їн
}

озр хов но в ртість доступних форм основних елементів живлення в грунт х кр їни з використ нням методики . рм нов т ін. ля розр хунків використ но вибірку з розширеної б зи д них грунтової, клім тичної т к ртогр фічної інформ ції л бор торії геоекофізики грунтів “ імені . . околовського”. икон но оцінюв ння основних елементів живлення грунтів кр їни з кл с ми в ртості.

лючові слов : оцінюв ння, в ртість, поживні елементи, $6 з$ д них.

розвитком ринкових мех нізмів в гр рному секторі кр їни особливо кту льними ст ють пит ння, пов'яз ні з розробкою методичних підходів до грошової оцінки сільськогоспод рських земель, ринок яких почне нез $б$ ром функціонув ти.

“ імені . . околовського” з пропонов но удоскон лений методичний підхід до грошової оцінки сільськогоспод рських земель $[1,2]$, з вд нням якого є визн чення фунд мент льної (б зової) в ртості земель, як відобр зить у грошовому вир женні потенційні можливості грунту для виробництв продукції. днією зі скл дових цієї оцінки є визн чення в ртості основних елементів живлення (мінер лізов ної т гідролізов ної форм зоту, рухомого фосфору т к лію).

ш мет - визн чити в ртість основних елементів живлення грунтів кр їни т оцінити їх 3 кл с ми в ртості.

б’єкт ми досліджень є основні типи грунтів кр їни. етоди досліджень ст тистичний, розр хунково- н літичний і к ртогр фічний.

ля розр хунків в ртості з п сів доступних елементів живлення використ но вибірку з розширеної втом тизов ної б зи д них ( ) “ л стивості грунтів кр їни”, розробленої л бор торією геоекофізики грунтів “ імені . . околовського” [3], як включ є пон д 2000 грунтових розрізів, розт шов них у всіх природних зон х кр їни. о вибірки з лучено д ні щодо вмісту рухомих форм фосфору т к лію в орному ш рі основних типів грунтів кр їни т щільності будови грунту в ш рі 0-25 см. ідсутність інформ ції з деякими тип ми грунтів дміністр тивних обл стей кр їни компенсов но д ними, які отрим но з ерж вного н уково-технологічного центру охорони родючості грунтів “ ентрдержродючість”.

озр хунок в ртості доступних форм основних елементів живлення викон но 3 методикою . 1) розр хунок з п сів рухомих сполук фосфору; 2) розр хунок з п сів рухомих сполук к лію; 3) визн чення розр хункових з п сів доступного для рослин зоту; 4) визн чення в ртості з п сів доступних елементів живлення в грунт х.

(C) ліско ., 2013 
ході досліджень проведено відповідні розр хунки т оцінено в ртість основних доступних поживних речовин грунтів кр їни, перелік яких н ведено у т блиці.

г лом для розр хунку в ртості поживних елементів у грунт х ми прийняли, що 1 кг діючої речовини дорівнює 3 в ртістю 5 кг зерн . в ртістю 250-300 дол. 31 т зерн це ст новить приблизно 1,5 дол. 31 кг NPK.

оди типів грунтів (з легендою до к рти грунтів м сшт бу 1: 1500 000)

\begin{tabular}{|c|c|}
\hline $\begin{array}{c}\text { од } \\
\text { грунту }\end{array}$ & ипи грунтів \\
\hline 1 & 2 \\
\hline 1 & $\begin{array}{l}\text { ерново-сл бкопідзолисті піщ ні т глинисто-піщ ні н д вньо люві льних водно- } \\
\text { льодовикових відкл д х і морені }\end{array}$ \\
\hline 2 & $\begin{array}{l}\text { ерново-середньопідзолисті супіщ ні н д вньо люві льних водно-льодовикових } \\
\text { відкл д х і морені }\end{array}$ \\
\hline 3 & $\begin{array}{l}\text { ерново-сл бкопідзолисті оглеєні (глеюв ті т глейові) піщ ні т глинисто-піщ ні } \\
\text { н д вньо люві льних водно-льодовикових відкл д х і морені }\end{array}$ \\
\hline 4 & $\begin{array}{l}\text { ерново-середньопідзолисті супіщ ні оглеєні (глеюв ті т глейові) н д вньо люві- } \\
\text { льних водно-льодовикових відкл д х і морені }\end{array}$ \\
\hline 5 & $\begin{array}{l}\text { ерново-середньо- т сильнопідзолисті поверхнево оглеєні н д вньо люві льних } \\
\text { водно-льодовикових відкл д х і морені ( ередк рп ття) }\end{array}$ \\
\hline 6 & $\begin{array}{l}\text { сно-сірі опідзолені т сірі опідзолені (не змиті т змиті) перев жно н лесових } \\
\text { пород х т глин х }\end{array}$ \\
\hline 7 & емно-сірі опідзолені (не змиті т змиті) перев жно н лесових пород $x$ т глин $\mathrm{x}$ \\
\hline 8 & орноземи опідзолені (не змиті т змиті) перев жно н лесових пород $x$ т глин $x$ \\
\hline 9 & емно-сірі регр дов ні (не змиті т змиті) перев жно н лесових пород х \\
\hline 10 & орноземи регр дов ні (не змиті т змиті) перев жно н лесових пород $x$ \\
\hline 11 & $\begin{array}{l}\text { орноземи типові м логумусні т сл бкогумусов ні (не змиті т змиті) н лесових } \\
\text { пород } \mathrm{x}\end{array}$ \\
\hline 12 & орноземи типові середньогумусні (не змиті т змиті) н лесових пород $x$ \\
\hline 13 & $\begin{array}{l}\text { орноземи звич йні м ло- т середньогумусні глибокі (не змиті т змиті) н лесових } \\
\text { пород } \mathrm{x}\end{array}$ \\
\hline 13 & і с мі міцелярно-к рбон тні (не змиті т змиті) н лесових пород $\mathrm{x}$ \\
\hline 14 & орноземи звич йні середньогумусні (не змиті т змиті) н лесових пород $x$ \\
\hline 15 & орноземи звич йні м логумусні (не змиті т змиті) н лесових пород $\mathrm{x}$ \\
\hline 15 & і с мі міцелярно-к рбон тні (не змиті т змиті) н лесових пород х \\
\hline 16 & орноземи звич йні м логумусні неглибокі н лесових пород х \\
\hline 16 & і с мі міцелярно-к рбон тні (не змиті т змиті) н лесових пород х \\
\hline 17 & $\begin{array}{l}\text { орноземи південні м логумусні т сл бкогумусов ні (не змиті т змиті) н лесових } \\
\text { пород х }\end{array}$ \\
\hline 17 & і с мі міцелярно-к рбон тні (не змиті т змиті) н лесових пород х \\
\hline 18 & орноземи перев жно солонцюв ті н в жких глин х \\
\hline $18 \mathrm{a}$ & орноземи н в жких глин х \\
\hline 19 & $\begin{array}{ll}\text { орноземи т дернові грунти щебенюв ті н елювії щільних безк рбон тних порід } \\
\text { (пісковиків т сл нців) }\end{array}$ \\
\hline
\end{tabular}




\begin{tabular}{|c|c|}
\hline 1 & 2 \\
\hline 20 & $\begin{array}{l}\text { орноземи т дернові грунти щебенюв ті н елювії к рбон тних порід (мергелю, } \\
\text { крейди, в пняку) }\end{array}$ \\
\hline 21 & орноземи типові з лишково солонцюв ті н лесових пород х \\
\hline 22 & орноземи південні з лишково солонцюв ті н лесових пород х \\
\hline 23 & учно-чорноземні перев жно н лесових пород х \\
\hline 24 & учно-чорноземні поверхнево солонцюв ті перев жно н лесових пород х \\
\hline 25 & учно-чорноземні глибоко солонцюв ті перев жно н лесових пород х \\
\hline 26 & емно-к шт нові з лишково солонцюв ті н лесових пород х \\
\hline 27 & емно-к шт нові солонцюв ті н лесових пород х \\
\hline 28 & шт нові солонцюв ті н лесових пород $\mathrm{x}$ \\
\hline 29 & учні н делюві льних т люві льних відкл д х \\
\hline 30 & учні солонцюв ті н делюві льних т люві льних відкл д х \\
\hline 31 & $\begin{array}{clllll}\text { учно-болотні т болотні } & \text { н } & \text { люві льних, делюві льних } & \text { т } & \text { водно- } \\
\text { льодовикових відкл д х } & & & & \\
\end{array}$ \\
\hline 32 & орфово-болотні грунти т торфовищ низинні \\
\hline 33 & олонці перев жно солонч кові \\
\hline 34 & учно-чорноземні т дернові осолоділі глейові грунти т солоді \\
\hline 35 & $\begin{array}{l}\text { ернові перев жно оглеєні піщ ні, глинисто-піщ ні т супіщ ні грунти в } \\
\text { комплексі із сл бкогумусов ними піск ми }\end{array}$ \\
\hline 35 & $\begin{array}{l}\text { ернові піщ ні т глинисто-піщ ні перев жно неоглеєні грунти в комплексі } \\
\text { iз сл бкогумусов ними піск ми т чорноземними піщ ними грунт ми, } \\
\text { місцями з кучугурним рельєфом }\end{array}$ \\
\hline 36 & ернові опідзолені суглинкові грунти т оглеєні їх види \\
\hline 37 & уроземно-підзолисті грунти т поверхнево оглеєні їх види \\
\hline 38 & $\begin{array}{l}\text { урі гірсько-лісові щебенюв ті т дерново-буроземні грунти в комплексі з } \\
\text { оглеєними їх вид ми н елювіїі-делювії щільних порід }\end{array}$ \\
\hline 39 & ерново-буроземні т гірсько-лучні грунти \\
\hline 40 & оричневі гірські щебенюв ті грунти н елювії-делювії корінних порід \\
\hline
\end{tabular}

озр хунки з свідчили, що м ксим льні з п си рухомого фосфору в грунт х кр їни ст новлять 1328 кг/Г, мінім льні - 197 кг/Г (див. рис. 1). р ктеризуючи вміст рухомих форм фосфору 3 клім тичними зон ми кр їни ми дійшли висновку, що н йвищий вміст рухомого фосфору є в зон льних грунт х ісостепової зони, дещо нижчий - у грунт х оліської т тепової зон. ля грунтів, розт шов них у зоні рп т, простежен тенденція зниження цього пок зник .

ет льне дослідження змін пок зник в меж х кожної зони д є змогу зробити т кі висновки. П си рухомих форм зон льних грунтів оліської зони колив ються в меж х 558-727 кг/г , н йвищий вміст м ють чорноземи регр дов ні середньосуглинкові, н йнижчий - дерново-сл бкопідзолисті супіщ ні т глинисто-піщ ні грунти т їхні оглеєні різновиди. 


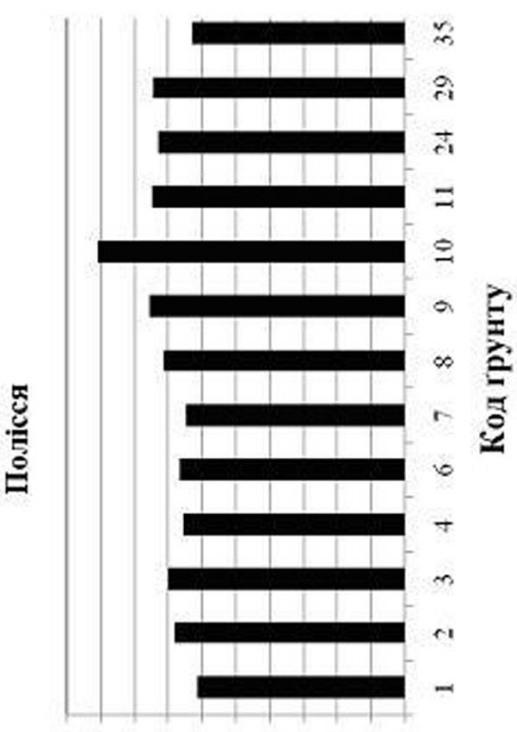

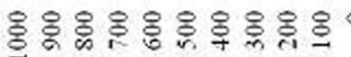

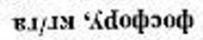

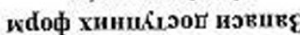

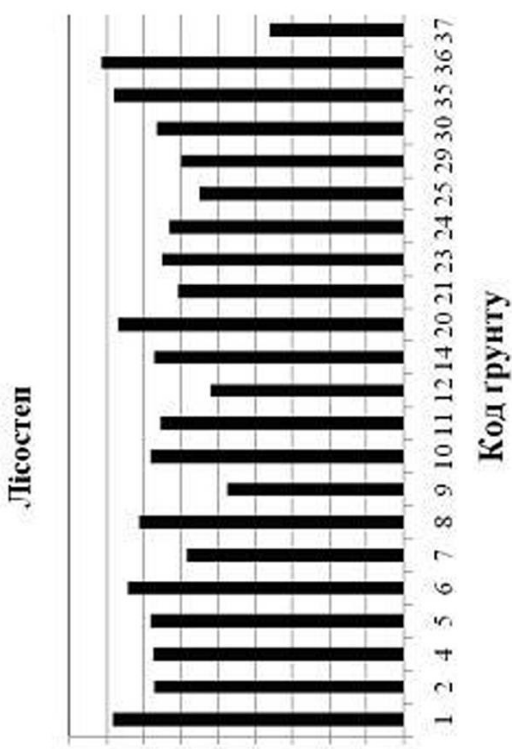

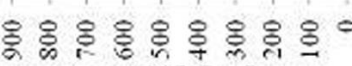

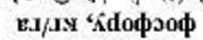

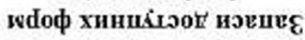

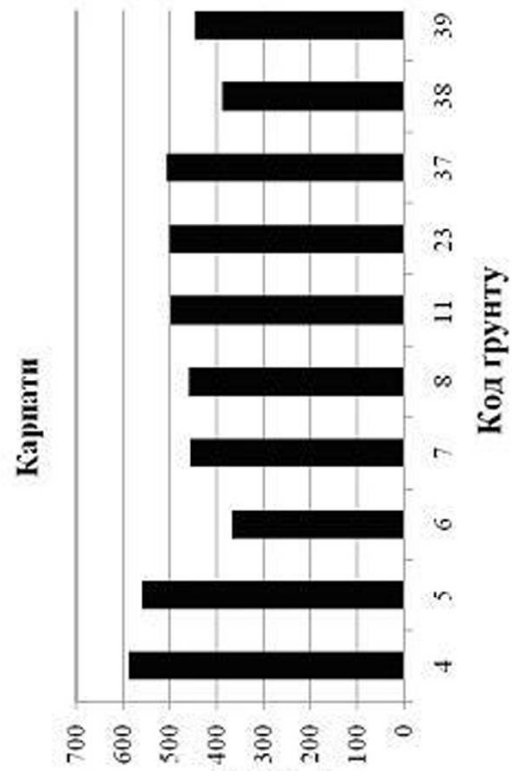

Ex/Jx 'Ádoфоoф

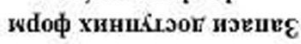

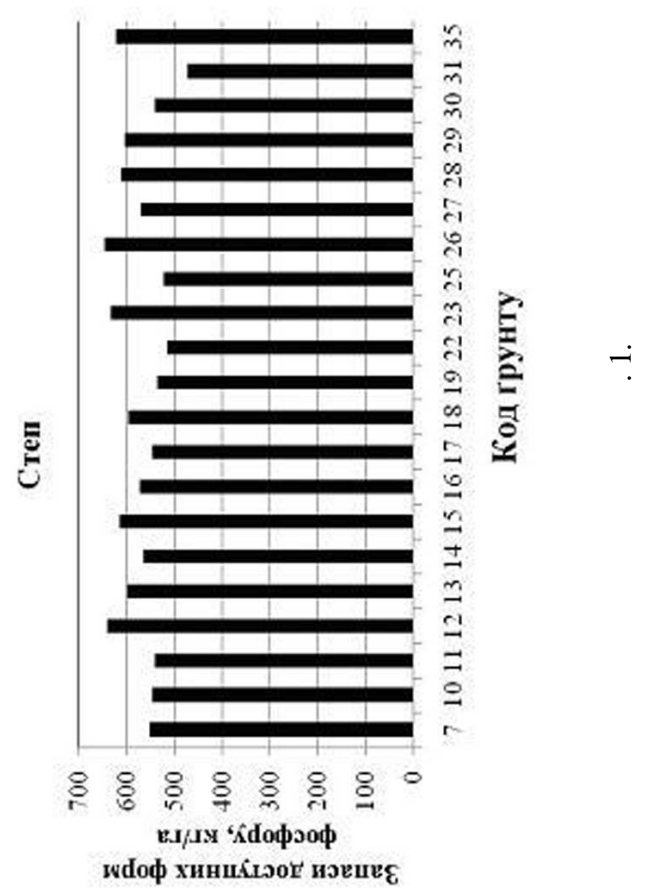



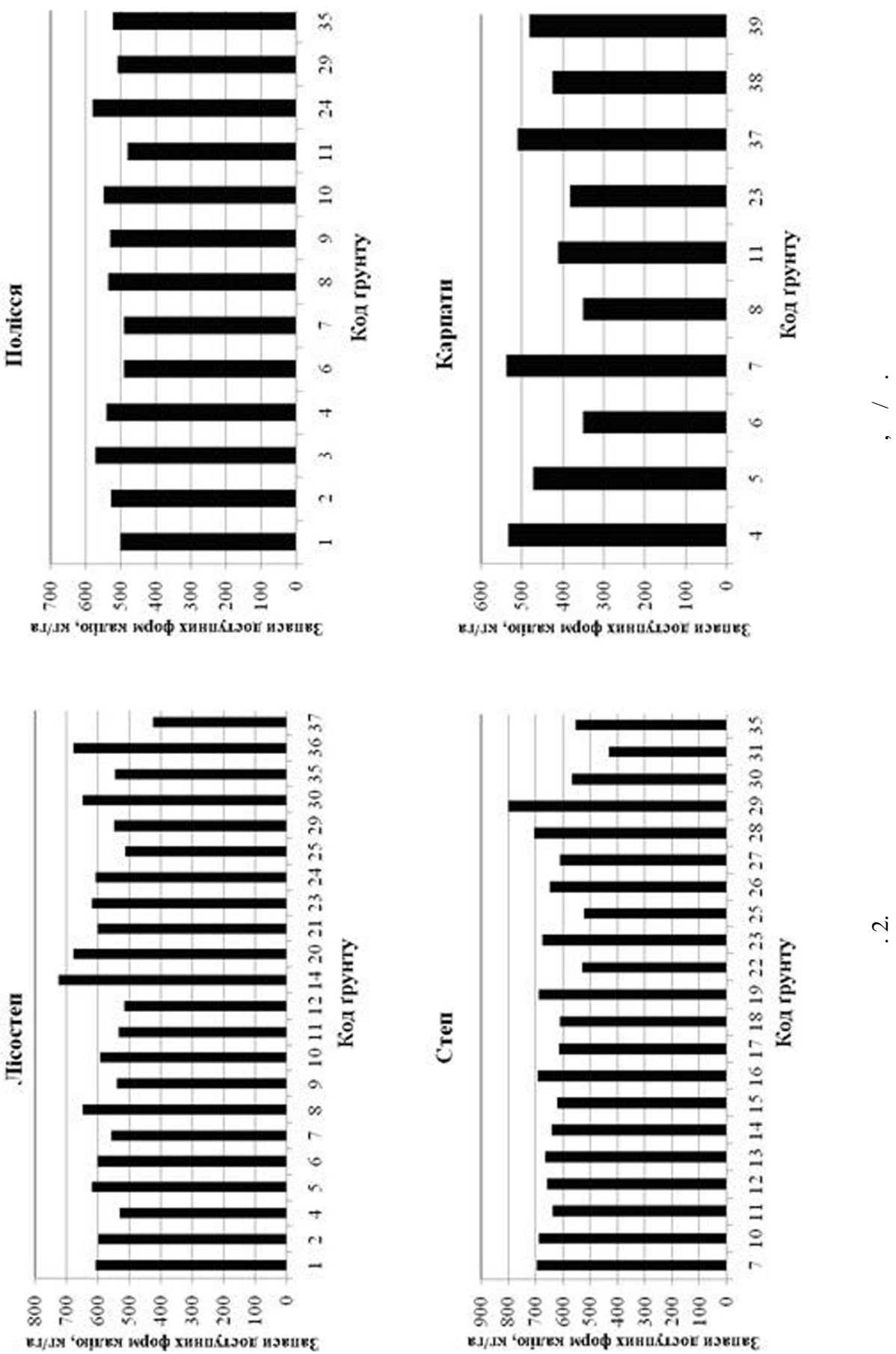

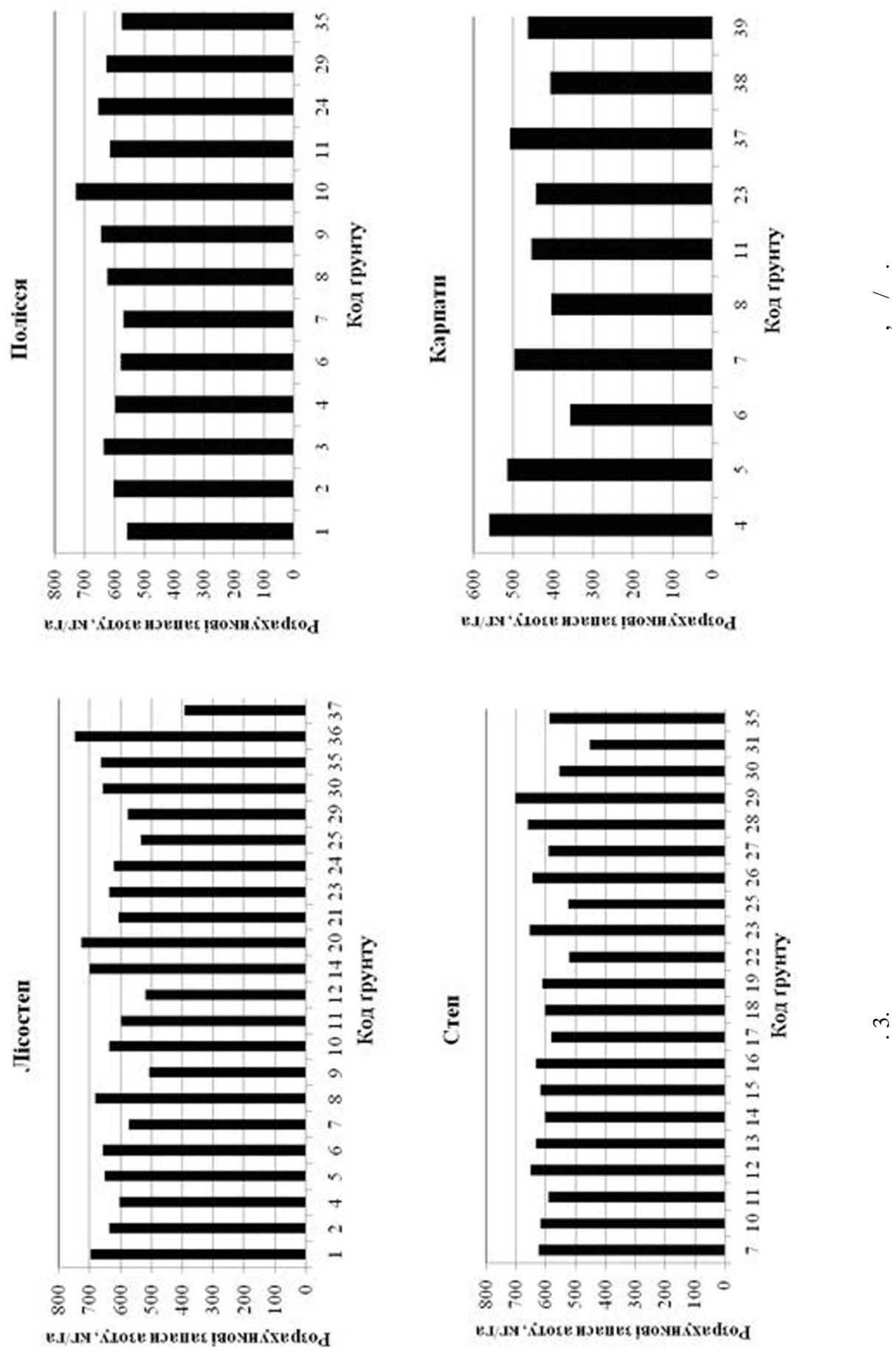
міст рухомих сполук фосфору в грунт $\mathrm{x}$ ісостепової зони колив ється в меж х 394-745 кг/г . цьому р зі мінім льні з п си цього поживного елемент м ють підзолисто-буроземні поверхнево глеюв ті грунти, м ксим льні - чорноземи звич йні потужні середньогумусні, чорноземи н миті т дернові грунти. рунти тепової зони м ють різний вміст рухомого фосфору: низький - у лучно-чорноземних сильносолонцюв тих солонч кув тих грунт х, високий - у чорнозем х типових т звич йних. рунти зони рп т збіднені н рухомі форми елемент порівняно з грунт ми інших зон, н йнижчі пок зники м ють сірі лісові в жкосуглинкові т буроземні кислі грунти, вміст рухомих форм фосфору в яких не перевищує 360 кг/г. ксим льні 3 п си елемент (н рівні 560 кг/г ) м ють дерново-середньопідзолисті грунти.

рис. 2 відобр жено вміст рухомих сполук к лію в грунт х кр їни. г лом цей пок зник змінюється в меж х 243-1233 кг/Г, н йнижчі пок зники м ють грунти

рп тської зони. грунт х оліської зони високий вміст рухомих форм цього елемент - у меж х 615-906 кг/Г . рунти ісостепової т тепової зон т кож м ють досить високий вміст рухомих форм поживного елемент - відповідно, н рівні 362-813 т 393-659 кг/Г.

р фічне відобр ження розр хункових з п сів доступного для рослин зоту пок з но н рис. 3. ей пок зник в ріює в меж х 220-1280 кг/Г. н чення пок зник $є$ н досить високому рівні для більшості досліджених грунтів. озр хунки д ють підст ви зробити висновок про те, що н йменші його зн чення х р ктерні для грунтів, розт шов них у рп тській зоні. прикл д, з п си зоту в рп т х не перевищують зн чення 560 кг/Г, у цьому р зі мінім льні з п си м ють сірі лісові грунти (до 359 кг/г ) т буроземи кислі (400 кг/г ), відповідно, досить високі зн чення м ють дерново-середньопідзолисті, темно-сірі опідзолені т підзолисто-буроземні грунти. ля грунтів оліської зони пок зник в ріює в меж х 558-727 кг/г, порівняно нижчі пок зники м ють дерново-сл бко- т середньопідзолисті грунти.

зоні ісостепу розр хункові з п си зоту, згідно з н шими дослідженнями, колив ються в меж х 394-745 кг/Г . Йвищі зн чення м ють дернові опідзолені грунти, чорноземи звич йні т чорноземи н миті, н йнижчі зн чення - підзолисто-буроземні поверхнево глеюв ті т темно-сірі опідзолені регр дов ні грунти. рунти тепової зони кр їни м ють розр хункові з п си елемент н рівні 452-714 кг/Г. одноч с з фіксов но тенденцію до зниження пок зник н деяких зон льних різновид х грунтів, с ме - н люві льних лучно-болотних к рбон тних т лучно-чорноземних сл бкосолонцюв тих грунт х.

підст ві проведених розр хунків визн чено в ртість основних елементів живлення грунтів кр їни в індекс х цінності у розр хунку н гект р т оцінено грунти 3 кл с ми в ртості (кл си I-IV). 'ясов но, що в ртість змінюється в досить широкому ді п зоні - від 661 до 3 312. г лом у меж х кр їни 7 \% грунтів м ють низьку в ртість основних елементів живлення (<1 500), що відповід $є$ кл су I; $56 \%$ м ють в ртість н рівні від 1500 до 2000 (кл с II), $22 \%$ - н рівні 2 000-2 500 (кл с III) і тільки для $1 \%$ грунтів х р ктерн в ртість $>2500$ (кл с IV).

к 6 чимо, більшість грунтів кр їни м є середній рівень з безпеченості основними елемент ми живлення ( зот, фосфор, к лій).

изьк в ртість поживних елементів х р ктерн для низки грунтів. е, н с мперед, грунти 3 хідних т гірських обл стей кр їни. прикл д, у рим це темнок шт нові ост точно солонцюв ті, солонці чорноземно-лучні глибокі солонч кув ті, коричневі к рбон тні грунти. хній гр нулометричний скл д в жкосуглинковий т 
глинистий. к рп тській обл. це підзолисто-буроземні поверхнево-глеюв ті грунти різного гр нулометричного скл ду - від легкосуглинкових до глинистих; буроземи кислі середньопотужні легко- т середньосуглинкового гр нулометричного скл ду т деякі зон льні грунти. осить б г то т ких грунтів в в но- $\mathrm{p}$ нківській обл. е, передусім, підзолисто-буроземні кислі поверхнево-оглеєні т сірі лісові грунти, дернові опідзолені оглеєні, підзолисто-буроземні поверхнево оглеєні грунти т буроземи кислі сильно щебенюв ті. p нулометричний скл д більшості 3 них легко- т середньосуглинковий. ернівецькій обл. це дерново-середньопідзолисті, темно-сірі опідзолені грунти т підзолисто-буроземні поверхнево глеюв ті. р нулометричний скл д цих грунтів перев жно т кож легко- т середньосуглинковий.

рунтів 3 в ртістю основних елементів живлення >2 500 індексів у розр хунку н 1 г в меж х кр їни досить неб г то. е чорноземи звич йні потужні середньогумусні середньосуглинкові т в жкосуглинкові, які розт шов ні перев жно у східних т південно-східних обл стях, с ме: ніпропетровській, рківській, уг нській т онецькій.

тже, з'ясов но, що н Йвищу в ртість з п сів доступних поживних елементів (в індекс х цінності у розр хунку н 1 г ) м ють чорноземи і дернові грунти середньот в жкосуглинкові, які розт шов ні перев жно у ісостеповій зоні кр їни. ідповідно, н йнижчу в ртість пок зник м ють грунти оліської (гірські р йони 3 хідних обл стей - підзолисто-буроземні поверхнево-глеюв ті грунти, буроземи кислі середньопотужні) т тепової зон кр їни (у рим - темно-к шт нові ост точно солонцюв ті, солонці чорноземно-лучні глибокі солонч кув ті, коричневі к рбон тні грунти).

\section{СПИСОК ВИКОРИСТАНОЇ ЛІТЕРАТУРИ}

1. едведев . . онитировк и к чественн я оценк п хотных земель кр ины . . едведев, . . лиско. - рьков : рук рня № 13, 2006. - 386 с.

2. едведєв . . рошов оцінк земель / . . едведєв, . . ліско // існик гр рної н уки. - 2006. - № 11. - . 63-68.

3. ктіонов . . труктур т порядок використ ння 6 зи д них “ л стивості грунтів кр їни" ( нструкція) / . . ктіонов , . . едведєв, . . вченко, . . ігун, . . ейко, . . кісько. - рків : постороф, 2010. - 96 с.

4. $р м$ нов . . пыт р зр ботки методики р счет индексов ценности земель сельскохозяйственного н зн чения н почвенно-экологической основе. оль почв в биосфере / . . рм нов, . . улг ков // руды н-т почвоведения, и . - 2003. - ып. 3 : ценк и учет почвенных ресурсов. - . 62-96.

m ття:н дійшл до ред кції 15.05.2013

доопр иьов н 31.05.2013

прийнят до друку 17.06.2013 


\title{
VALUATION OF SOIL NUTRIENTS COST IN UKRAINE
}

\section{Iryna Plisko}

\author{
The National Science Center \\ "Institute for Soil Science and Agricultural Chemistry named after O. N. Sokolovsky", \\ Chaikovskiy Str., 4, UA - 61024, Kharkiv, Ukraine
}

The calculation of the cost of major nutrients available forms in soils of Ukraine using the I. Karmanov technique is performed. For calculations a sampling from the extensive database of soil, climate and map information in laboratory of soil geoekophysics of NSC "ISSAR named after O. N. Sokolovsky" is used. Evaluation by class value of major soil nutrients of Ukraine is done.

Key words: evaluation, cost, nutrients, database.

\section{рин Лиско}

циион льный н учный центр “ нститут почвоведения и грохимии имени . . околовского”, ул. йковск $я, 4,61024$, г. рьков, кр ин

роведено р счет стоимости доступных форм основных элементов пит ния почв кр ины с использов нием методики . рм нов . ля р счетов использов но выборку из р сширенной б зы д нных почвенной, клим тической и к ртогр фической информ ции л бор тории геоекофизики почв “ имени . . околовского”. роведено оценив ние основных элементов пит ния почв кр ины по кл сс м стоимости.

лючевые слов : оценк, стоимость, пит тельные элементы, $6 з$ д нных. 